\title{
The Attitude of Economic Students and Lecturers toward Economic English Material Based on Shariah Economy System
}

\author{
Syamsul Una \\ Universitas Negeri Makassar, Jln. Bonto Langkasa, Kampus Gunung Sari, Makassar, South Sulawesi, Indonesia \\ Djamiah Husain \\ Universitas Negeri Makassar, Jln. Bonto Langkasa, Kampus Gunung Sari, Makassar, South Sulawesi, Indonesia
}

Abd. Halim

Universitas Negeri Makassar, Jln. Bonto Langkasa, Kampus Gunung Sari, Makassar, South Sulawesi, Indonesia

\begin{abstract}
This research aimed to investigate Economic students and lecturers' attitude toward economic English material based on shariah economy system. The material was the new material design that combined economic English in general and shariah economy concept in a teaching and learning material. This research is survey research. It was held at Economy Faculty of Dayanu Ikhsanuddin University Baubau Indonesia in 2015/2016 academic year. This research was limited to analyze both Economic students and lecturers' attitude toward economic English material based on shariah economy system. The Participants of the study were 100 Economic students and 20 Economic lecturers. The instruments used were questionnaire and interview. All participants were invited to respond to questionnaires. And they then participated in follow-up interviews. The results of the study showed that the main score of students' attitude was $\mathbf{4 2 . 2 4}$ and lecturers' attitude was 41.50. From the main above indicated that both Economic students and lecturers had positive attitude toward economic English material based on shariah economy system.
\end{abstract}

Index Terms - economic English, attitude, shariah economy system

\section{INTRODUCTION}

Teaching English for tertiary education students in Indonesia, especially for non-English majoring students, still faces many problems. The students learning achievements or their English language skills are still relatively low. Many research results argue that Indonesian students have low English proficiency (Hamra, 1996 and Kwelju, 2003). The success of learning English is actually still far the success of the research related to the teaching and learning English. This is because there are still many obstacles in implementing the result of the studies such as cultural factors, paradigm, and the way of lecturers and students in teaching and learning.

The English course in Economy Faculty of dayanu Ikhsanuddin University falls under the category of English for Specific Purpose (ESP). But in implementation there are some problems happened such as: (1) The learning material used by lecturer is General English (GE) that taken not based on the process of students needs analysis; (2) Economic English is taught in Indonesian, (3) Students have very limited time to practice and increase their language skills in the classroom. This condition makes students be difficult to muster the language: (3) The learning model used is a conventional model where learning English is only focused on the lecturers, the lecturers who explain the material and students more listen. Whereas, the use of unsuitable learning model in teaching and learning process can be lead to boredom, lack of understanding, and monotonous teaching and learning so, students are less motivated to learn.

In overcoming the problems, then the application of Economic English material based on Shariah economy system is important because of several reasons including (1) In learning, economic English material based on shariah economy system implements the Students Centered Learning (SCL) and the learning approach used is Communicative Language Teaching (CLT). The use of SCL and CLT approach are able to increase students' independence learning, the ability to work in teams, and learn to reflected the existing circumstances. (2) The learning material is developed based on the specific needs analysis, (3) The material contains the English as modern knowledge and shariah economy as religious knowledge. Johari and Mustaffha (2014) combination of modern sciences and religious sciences are needed in an academic curriculum. In other words, he also confirms that students who learn integrated knowledge they will be good not only in knowledge but also in skills and spiritual.

Based on all explanations above and to make sure that Economic English material based on shariah economy system is necessary to be used in teaching Economic English. Therefore, the researcher needs to be known "The attitude of economic Lecturers and Students toward economic English material based on Shariah economy system". Whatever 
Garner (1985) explained that the success of learning the second and foreign language would mostly likely seen to depend on attitude of learners.

\section{LITERATURE REVIEW}

\section{A. English for Specific Purposes}

Economic English material based on shariah economy system is a part English for Specific Purposes (ESP), it is in the branch of "English for Business and Economic (EBE)".

Hutchinson and Waters (1987) defines that ESP is the model of language learning that all materials and situations are designed based on the learners' target of learning. Gatehouse (2001) argues that in ESP, the language contexts are determined based on the results of specific need analysis in target workplace.

Carter (1983) divides ESP into three types: (1) English as restricted language; (2) English for Academic and Occupation Purposes; and (3) English with specific topics. Further, Hutchinson and Waters (1987) broke English for Academic and Occupation purposes into three parts: (1) English for Science and technology (EST); (2) English for Business and Economic (EBE); and (3) English for Social Studies (ESS).

Strevens (1988) identifies ESP into absolute and variable characteristics: Absolute Characteristics, English teaching is designed for: (1) Finding specific needs of the learners; (2) The content, for example 'themes' and 'topics' must be related to the particular disciplines, occupations and activities; (3) The language center can be in syntax, lexis, discourse, semantics, etc. Variable characteristics, ESP may be, but is not necessary: (1) The language skills are learned to be restricted for example 'reading skill' only; (2) Pre-ordinal methodology is not used in teaching

From the explanation, the writer explains that English for Specific Purpose is designed to meet specific needs of the learner. The objective of ESP is to make the learners understand the language needed in the certain domain, occupation or vocation.

\section{B. Economic English Material Based on Shariah Economy System}

Economic English material based on Shariah economy system is designed especially for economic students in the university. The material is designed through the process of specific needs analysis, so that, the material is expected to be suitable for the students' needs and levels.

In the aspects of language skills, economic English based on shariah economy system is to apply integrated skills namely: (1) Listening, students should be able to understand and identify the arguments and the points of someone talks; (2) Speaking, students should be able to participate effectively in speech such as speaking individually, being a presenter at the seminar, and including how to develop an argument in the discussions; (3) Reading, students can understand various of texts that are from textbooks, articles, newspaper, and the internet; (4) Writing, students can produce understandable and well strured writing, and also the students should have ability to paraphrase and use phrases appropriately.

In the aspect of learning approach, it is used communicative language teaching (CLT). Harmer (2001) explains that the main principle of CLT is to train the students to use language forms appropriately in the variety of contexts for the variety of purposes. While Richards and Rogers (2007) explain that the goal of language teaching which the materials taught include four language skills into communicative exercises. The underlying theory of language in CLT logically views language as communication. The goal of teaching is to develop communicative competence. Further, Richards and Rogers (2007) describes the principles of communicative language teaching: (1) Learners learn a language through communicative process; (2) The goal of classroom activities is authentic and meaningful communication; (3) Important dimension of communication is fluency; (4) The integration of different skills is needed in communication; (5) Teaching and learning process is a process of creative activities that involves trial and error.

In teaching Economic English based on Shariah economy system is used the Learner-centered classroom. Husain (2011) explains that learner-centered classroom usually involved a number of features, which fit the principles of Communicative Language teaching. The dimensions of function, structure, topic demonstrated in many current communicative materials are essentially learner-centered. Grunet (1997) described learner-centered with particular emphasis on enhancing students learning by a learner-centered to college education ask you to consider how each and every aspect of your course can most effective to support students learning. Weatherholz (2003) argues that in the learner-centered classroom students learn to access their own work and anticipate in the assessment of their counterparts work, which leads them to become self-directed learners and long-life learning.

In the aspect of content, economic English based on shariah economy system uses vocabulary, sentence, theme, title that are used in teaching and learning related to shariah economy practice. In this case, the students are given the complete explanation so that they can analyze various economic problems. Through this study, students are expected to be able to participate in a variety of functions in businesses and public sectors. Students are prepared to be a financial analyst, economic consultant, human resource managers, policy advisers, researchers, etc.

\section{Concept of Attitude}

Attitude has a close relationship with motivation. They are interconnected each other. There are many definitions of the term. Ellof \& Ebersohn (2004) Attitude is belief and opinion that can influence individuals to behave in certain 
ways. Brown (2001) states that attitude is indicated by the large proportion of emotional involvement such as feeling, self, a relationship in community (p. 61). Garner (1985) explains that attitude is the evaluative reaction to the certain object which is inferred based on the individual's belief or opinion about it (p. 91). Attitude is acquired through experience and has a direct influence on behavior. Strong or positive attitude can predict behavior more effectively than weak or negative ones, the attitude formed by personal experience is often stronger in nature. Self-awareness increases the consistency between our attitude and overt behavior. Students attitude is commonly believed to hold a central role in language learning. According to Morgan (2011) states that attitude is a tendency to respond positively (favorable) or negatively (unfavorable) to certain objects, persons, or situations. Attitude refers to the process of action, the readiness to respond to certain things or people whether like or dislike.

Gardner (1985) argues that attitude is attitude directly related to motivation which is in turning to the second language learning. In the other words, attitude must be seen as motivational supports and not as factors, which have a direct relation to the second language learning. Someone who has the positive attitude towards something or someone will show her/his positive behavior directly. Moreover, if someone has negative attitude towards something or someone also directly show her/his negative behavior. On the other hand, in the other word, attitude relates to the individual's internal state in learning to a certain group social identity.

The definition above relates to the internal condition of individuals, in this case, the mental aspects stimulate the response of the individual choice and keep it consistent. Human conditions are consistently changed as well as their perceptions. The attitude of individual may become permanent according to the influence upon the individual response to the certain object or thing. There are many factors affecting students' attitudes. However, the researcher focuses only on the student' attitudes toward teaching and learning, they are: interest, motivation, lecturers, and learning materials.

\section{METHOD}

A total of 100 Economic students and 20 Economic lecturers participated in this research. All of the Economic students had joined Economic English in their class. After participating in filling the attitude questionnaires, the same participants were invited to take part in follow-up interviews. This research is survey research. Both questionnaires and interviews were used to gain an in-depth insight into the attitude of Economic students and lecturers toward economic English material based on shariah economy system. (Mackey and Gass, 2005) explains that triangulation or the combination between instruments can ensure the validity of research result. The interview here was provided as supplementary and confirmatory data gotten for attitude questionnaires. In analyzing the data collected include the frequency and descriptive statistics were used for analyzing the results of the questionnaires. SPSS 17 version was employed for data analysis. And the data gotten from the interview were read line by line and translated into English. Afterward, the emerging themes were identified and reported.

\section{FINDINGS AND DISCUSSIONS}

\section{A. Findings}

\section{Students and Lecturers' attitude toward Economic English Material based on Shariah Economy System}

The analysis of students and lecturers' answers to each item of attitude questionnaires can be seen in the following table: 
TABLE 1.

PERCENTAGE OF STUDENTS' AND LECTURERS' ANSWER TO THE ATTITUDE QUESTIONNAIRES

\begin{tabular}{|c|c|c|c|c|c|c|c|c|}
\hline The Items of Questionnaires & $\begin{array}{l}\text { Participants } \\
(\%)\end{array}$ & $\begin{array}{l}\text { Strongly } \\
\text { disagree } \\
(\%)\end{array}$ & $\begin{array}{l}\text { Disagree } \\
(\%)\end{array}$ & $\begin{array}{l}\text { Undecided } \\
(\%)\end{array}$ & $\begin{array}{l}\text { Agree } \\
(\%)\end{array}$ & $\begin{array}{l}\text { Strongly } \\
\text { agree } \\
(\%) \\
\end{array}$ & $\begin{array}{l}\text { Average } \\
\text { Score }\end{array}$ & SD \\
\hline \multirow{2}{*}{$\begin{array}{l}\text { Economic English material based on } \\
\text { shariah economy system can be used } \\
\text { for teaching economic English. }\end{array}$} & Students & 0 & 0 & 0 & 75 & 25 & 4.26 & 0.44 \\
\hline & Lecturers & 0 & 0 & 10 & 60 & 30 & 4.25 & 0.64 \\
\hline \multirow{2}{*}{$\begin{array}{l}\text { Economic English material based on } \\
\text { shariah economy system can replace } \\
\text { teaching material before. }\end{array}$} & Students & 0 & 3 & 17 & 50 & 30 & 4.08 & 0.77 \\
\hline & Lecturers & 0 & 5 & 25 & 55 & 15 & 3.70 & 0.80 \\
\hline \multirow{2}{*}{$\begin{array}{l}\text { Economic English material based on } \\
\text { shariah economy system is useful for } \\
\text { Economic Students. }\end{array}$} & Students & 0 & 0 & 5 & 46 & 49 & 4.43 & 0.61 \\
\hline & Lecturers & 0 & 0 & 5 & 30 & 65 & 4.60 & 0.60 \\
\hline \multirow{2}{*}{$\begin{array}{l}\text { Students can be motivated to study } \\
\text { economic English material based on } \\
\text { shariah economy system. }\end{array}$} & Students & 0 & 0 & 16 & 60 & 24 & 4.08 & 0.63 \\
\hline & Lecturers & 0 & 0 & 15 & 65 & 20 & 4.10 & 0.64 \\
\hline \multirow{2}{*}{$\begin{array}{l}\text { Students can improve their English } \\
\text { skills by studying Economic English } \\
\text { material based on shariah economy } \\
\text { system. }\end{array}$} & Students & 0 & 0 & 7 & 54 & 39 & 4.31 & 0.61 \\
\hline & Lecturers & 0 & 0 & 15 & 45 & 40 & 4.25 & 0.71 \\
\hline \multirow{2}{*}{$\begin{array}{l}\text { Studying economic English material } \\
\text { based on shariah economy system } \\
\text { can improve Economic competence. }\end{array}$} & Students & 0 & 0 & 10 & 58 & 32 & 4.29 & 0.66 \\
\hline & Lecturers & 0 & 0 & 5 & 55 & 40 & 4.35 & 0.59 \\
\hline $\begin{array}{l}\text { Students will be more active in } \\
\text { English class if it is taught using }\end{array}$ & Students & 0 & 0 & 16 & 64 & 20 & 4.04 & 0.60 \\
\hline $\begin{array}{l}\text { Economic English material based on } \\
\text { shariah economy system. }\end{array}$ & Lecturers & 0 & 0 & 30 & 45 & 25 & 3.95 & 0.76 \\
\hline \multirow{2}{*}{$\begin{array}{l}\text { Students can be interested to study } \\
\text { economic English material based on } \\
\text { shariah economy system }\end{array}$} & Students & 0 & 0 & 7 & 64 & 29 & 4.23 & 0.57 \\
\hline & Lecturers & 0 & 0 & 15 & 70 & 15 & 4.05 & 0.60 \\
\hline \multirow{2}{*}{$\begin{array}{l}\text { I want to (I hope my students can) } \\
\text { Study Economic English material } \\
\text { based on shariah economy system }\end{array}$} & Students & 0 & 0 & 5 & 40 & 55 & 4.50 & 0.59 \\
\hline & Lecturers & 0 & 0 & 10 & 60 & 30 & 4.20 & 0.62 \\
\hline \multirow{2}{*}{$\begin{array}{l}\text { Economic English material based on } \\
\text { shariah economy system can help in } \\
\text { looking for jobs. }\end{array}$} & Students & 0 & 0 & 18 & 62 & 20 & 4.02 & 0.62 \\
\hline & Lecturers & 0 & 0 & 20 & 45 & 35 & 4.05 & 0.83 \\
\hline
\end{tabular}

The table 1 above shows that distribution of students and lecturers who answer the questions of attitude questionnaires indicates that most of students and lecturers choose agree and strongly agree but less of them choose undecided and disagree. Further, from all the questions only question number 2 (Economic English material based on Shariah economy system can replace teaching material before) that there are some students and lecturers answer 'disagree' because they regard that the material before still also feasible to be used in teaching economic English.

Further, below will be also explained about the frequency and percentage of students and lecturers' attitude toward the economic English material based on shariah economy system.

TABLE 2.

FREQUENCY AND PERCENTAGE OF STUDENTS AND LECTURERS' ATTITUDE

\begin{tabular}{|c|c|c|c|c|c|c|}
\hline \multirow[b]{2}{*}{ Range of score } & & \multirow[b]{2}{*}{ Classification } & \multicolumn{2}{|c|}{ Students } & \multicolumn{2}{|c|}{ Lecturers } \\
\hline & & & $\mathrm{F}$ & $\%$ & $\mathrm{~F}$ & $\%$ \\
\hline $43-50$ & 5 & High Positive & 48 & 48 & 6 & 30 \\
\hline $35-42$ & 4 & Positive & 52 & 52 & 13 & 65 \\
\hline $26-34$ & 3 & Neutral & 0 & 0 & 1 & 5 \\
\hline $18-25$ & 2 & Negative & 0 & 0 & 0 & 0 \\
\hline \multirow[t]{2}{*}{$10-17$} & 1 & High Negative & 0 & 0 & 0 & 0 \\
\hline & Total & & 100 & 100 & 20 & 100 \\
\hline
\end{tabular}

Table 2 illustrates that most of the students and lecturers' attitude were in the positive and high positive. The aggregate percentage of students' attitude, categorized as high positive attitude was 48 percent (48 students), positive attitude was 52 present (52 students) and none of the students in neutral, negative, and high negative attitude. While for the lecturers, categorized as high positive was 30 percent (6 lecturers), positive attitude was 65 percent (13 lecturers), neutral was 5 percent (1 lecturer), and none of lecturers in negative and high negative attitude. Based on the explanation, the students and the lecturers' attitude toward economic English material based on shariah economy system can be also seen in the following figure. 


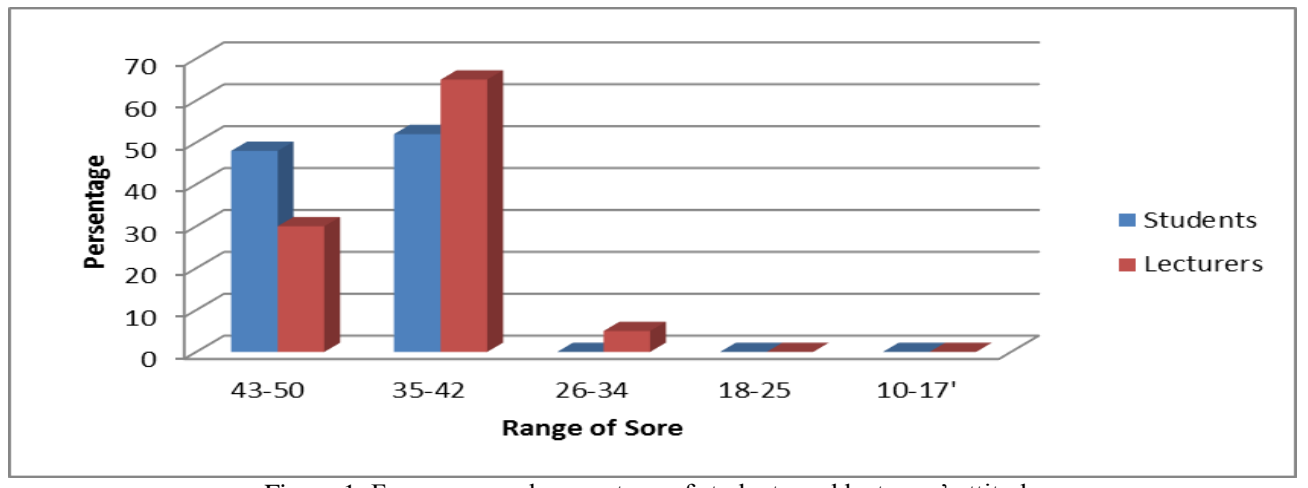

Figure 1. Frequency and percentage of students and lecturers' attitude

Further, the data of descriptive statistic of students and lecturers' attitude toward economic English material based on shariah economy system can be also seen in the following table:

TABLE 3.

\begin{tabular}{llllll}
\multicolumn{5}{c}{ DESCRIPTIVE STATISTIC OF STUDENTS AND LECTURERS’ ATTITUDE } \\
\hline Variables & N & Minimum & Maximum & Mean & Std. Deviation \\
\hline Students & 100 & 37 & 48 & 42.24 & 2.10 \\
\hline Lecturers & 20 & 34 & 46 & 41.50 & 2.80 \\
\hline
\end{tabular}

Table 3 illustrates that the mean score of students attitude was 42.24 with the higher score was 48 , the lowest score was 37 , and the standard deviation was 2.10 . From the explanation above especially the main score of the students' attitude that was existed in the range of score 35-42, it means that the students had the positive attitude toward economic English material based on shariah economy system. While the mean score of lecturers' attitude was 41.50 with the higher score was 46 , the lowest score was 34 , and the standards deviation was 2.80 . It could be explained that the mean score of the lecturers' attitude also existed range of score 35-42, it means that the lecturers also had positive attitude toward economic English material based on shariah economy system.

\section{B. Discussions}

Students and Lecturers of Economy Faculty at Dayanu Ikhsanuddin University have positive attitude toward Economic English based on shariah economy system. It is very important for the success of teaching and learning economic English. Gardner (1985) stated that success of learning second or foreign language would mostly likely be seen to depend on the attitude of learners. Most of the students and lecturers agreed to use economic English material based on shariah economy system in teaching economic English in Economy Faculty of Dayanu Ikhsanuddin University because of some reasons: (1) To know shariah economic vocabularies and terminologies in English, (2) Directly know both economic English in general, and shariah economy (3) To prove economic outlook, (4) To take a stance toward the trend of Shariah Economy in the world, and (5) To help in improving economic English competence to face ASEAN Economic Community (AEC) and the trend of shariah Economy in the world now.

Most students and lecturers believed that economic English material based on shariah economy system could be useful for students to improve both their English language skills such as listening, speaking, reading, writing and English language components such as vocabulary, pronunciation, and grammar. In the other hand, the students also could know the economic knowledge in content especially Shariah Economic. In this case the students could be trained to be able: (1) To take notes for the extended lecturers, including how to understand the arguments and identify the speaker's point of view; (2) How to take part effectively in seminar, including how to develop arguments and give respond for questions and comments. (3) How to understand a wide range of texts, from academic textbooks, articles, newspaper, internet, including how identify the complex sentences and writer's message in the texts; (4) How to develop students' knowledge and use of key vocabulary, both in the field of Economy shariah and of academic study in general.

The students expressed their enthusiasm in joining economic English class that was taught by using economic English material based on shariah economy system. Because they regarded that the material can help them to be able to compete with domestic and international work seeker. Because one of the weaknesses of job seekers from Indonesia was low in English proficiency. Dirgayasa (2014) explained that Indonesian graduates are commonly not able to compete to get job with graduates from other countries because they are justified to have better English competencies than Indonesian (p. 112).

\section{CONCLUSION}

This study found that Lecturers and students in Economy Faculty of Dayanu Ikhsanuddin University have positive attitude toward economic English material based on shariah economy system. The means scores of the students' attitude is 42.24 and lectures' attitude is 41.50, indicate their positive attitude towards the Economic English Material based on the Syariah Economy System. There are several reasons for both the students and lectures for expressing their positive 
attitude toward the material they are: (1) By studying to material the students can know shariah economic vocabularies and terminologies in English, (2) Directly know both economic English in general, and shariah economy concept in specific (3) To prove economic outlook, (4) To take a stance toward the trend of Shariah Economy in the world, and (5) To help in improving economic English competence in order to find the job and to face ASEAN Economic Community (AEC).

\section{REFERENCES}

[1] Brown, H. Douglas. (2001). Teaching by Principles. An Interactive Approach to Language Pedagogy. New York: Addison Wesley Longman Inc.

[2] Carter, D. (1983). Some Propositions about ESP. The ESP Journal, 2 (P. 131-137).

[3] Dirgayasa, I.W. (2014). Survey of English and Learning Process in Maritme Education and Training in Indonesia: A Case Study in Private MET in Indonesia. Journal of English Language Teaching; Vol. 7, No. 7; 2014; ISSN 1916-4742 E-ISSN 1916-4750. files.eric.ed.gov/fulltext/EJ1076016., 111-119.

[4] Eloff, I. \& Ebersohn, L. (2004). Keys to educational psychology. Cape Town: UCT Press.

[5] Gardner, R. C. (1985). Social psychology and second language learning: The Role of Attitudes and Motivation. London: Edward Arnold.

[6] Gatehouse, K. (2001). Key Issues in English for Specific Purposes (ESP) Curriculum Development. The Internet TESL Journal, Vol. VII, No. 10, October 2001. http://iteslj.org/Articles/Gatehouse-ESP.html (accessed 14/11/ 2015).

[7] Grunert, J. (1997). The Course Syllabus. A Learning-Centered Approach. Bolton: Anker.

[8] Hamra, A. (1996). Developing questioning competences through radio reading. Jurnal Jaringan (Journal of Network). Vol. 1, No. 3, 190-195

[9] Harmer, J. (2001). The Practice of English Language Teaching. London: Longman.

[10] Husain, D. (2011). Fostering Autonomous Learning Inside and Outside the Classroom in Language learning (first edition). Makassar: The UNM Publisher.

[11] Hutchinson, T., \& Waters, A. (1987). English for specific purposes: A learning centered approach. Cambridge: Cambridge University Press.

[12] Johari, N., \& Mustaffha, N. (2014). Harmonization of Accounting Curriculum: Integration of Islamic Values. In prosiding of Synergizing Knowledge on Management and Muamalah. E-ISBN:978-983-92-2., 978-983.

[13] Kwelju, S. (2003). Vocabulary and Lexicogrammatical units: Graduate Students' Main problem in Reading their textbooks. Linguistic Indonesia. Jurnal Ilmiah Masyarakat Linguistic Indonesia (Scientific Journal of Indonesian Linguistic Society, Vol 1, $35-56$.

[14] Mackey, A., \& Gass, S. M. (2005). Second language research: Methodology and design. Mahwah, NJ: Lawrence Erlbaum Associates.

[15] Morgan. (2011). Meaning of attitude. Journal of education (online). http://www.impove spoken English.org/html. (accessed $12 / 1 / 2015)$.

[16] Richards, J. C. and Rodgers. T. S. (2007). Approaches and Methods in Language Teaching. Cambridge: Cambridge University Press.

[17] Strevens, P. (1988). ESP after Twenty Years: A Re-appraisal. In M. Tickoo (Ed.), 1-13.

[18] Weatherholtz, D. B. (2003). Learner-Centered teaching: Five Key Changes to Practice-book Review Theory into Practice. San Francisco: Jossey-Bass.

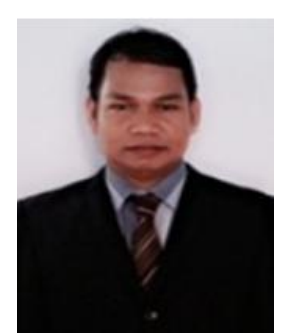

Syamsul Una was born in Rukuwa, Wakatobi on $21^{\text {st }}$ February 1982. He is currently a doctoral candidate of English Education at State University of Makassar, Indonesia. He received his master of English Education in the same university namely State University of Makassar in 2013.

$\mathrm{He}$ is a lecturer in English Education Study Program of Dayanu Ikhsanuddin University, Indonesia. He had published many articles and the last three articles published: (1) Improving Student' Speaking skills through Students Centered Learning (SCL), Published in journal of Akademika 2013. (2) The use of Parallel-Team Teaching: The case of Teaching Speaking for Economics Students in Indonesian Context, published in Asian EFL Journal Professional Teaching Articles 2016. (3) Needs Analysis of English for Specific Purposes (Development of Economic English Based on Shariah Economy System), published in Asian EFL Journal 2017.

Mr. Una, M.Pd (M.Ed) had held several positions: from 2007-2009 became vice of dean at Educational Faculty of Dayanu Ikhsanuddin University. 2011-2013 became a secretary of research institution and community services at Dayanu Ikhsanuddin Univesrity. In the same year namely 2011-2013 became Chief Editor at AKADEMIKA Journal of Dayanu Ikhsanuddin University. And from 2012 until now, he is currently the member of Asian TEFL Organization. 


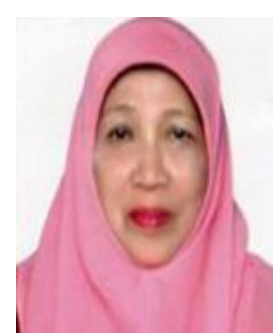

in 2017.

Prof. Djamiah had held several positions: from 2000-2003 became Director of Center of Language Services (CLS), Faculty of Language and Literature. 2005-2007 became a Consultant of School funding Managemnt in Dinas Pendidikan Provinsi Sulawesi Selatan, Indonesia. And 2008-2012 became the Head of research and Woman's Empowerment, Research Institution of State University of Makassar.

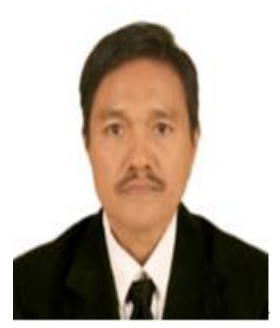

Abd. Halim was born in Ujung Pandang on $2^{\text {nd }}$ November 1962. He graduated his gradate program (S1) of English Education at Teacher's collage, Indonesia 1987. He graduated his Post Graduate (S2) of American Study at Ganjah Mada University, Indonesia 1998. And he completed his Doctoral Program (S3) of Linguistics at Hasanuddin University, Indonesia 2013.

$\mathrm{He}$ is a lecturer at Faculty of language of literature of State University of Makassar. His Major Field of Study is Literature in English Language Teaching. His last four publications: (1) Journal. Self-Regulating Capacities as the Key to Boosting up English Metaphor, in English Language Teaching Canadian Center of Science and Education, in 2013. (2) National Seminar Proceeding, English Teachers' Perception toward teacher guidebook on Literature Teaching, in 2016. (3) International Conference Proceeding TESOL Indonesia, Implementing the English Literature Based-Course Book for Senior High School Students, in 2016.

Dr. Halim had held several positions: from 1988-1999 became the Secretary of Business English Study Program, State University of Makassar. 2003-2008 became the Head of Business English Study Program, State University of Makassar. 2000-2008 became member of Senate at Language and Literature Faculty, State University of Makassar. 2010 become the Team member of Teachers Certification Material. 2015-now became the Deputy of dean at Language and Literature Faculty, State University of Makassar, Indonesia. 